\title{
Periostin in Allergy and Inflammation
}

\author{
Eva Sonnenberg-Riethmacher ${ }^{1,2}$, Michaela Miehe $^{3}$ and Dieter Riethmacher ${ }^{1,2 *}$ \\ ${ }^{1}$ Department of Biomedical Sciences, School of Medicine, Nazarbayev University, Nur-Sultan, Kazakhstan, ${ }^{2}$ Department of \\ Human Development and Health, School of Medicine, University of Southampton, Southampton, United Kingdom, \\ ${ }^{3}$ Department of Biological and Chemical Engineering - Immunological Biotechnology, Aarhus University, Aarhus, Denmark
}

\section{OPEN ACCESS}

Edited by:

Philippe Saas,

INSERM U1098 Interactions Hôte-

Greffon-Tumeur \& Ingénierie Cellulaire et Génique, France

Reviewed by:

Noriyuki Yanagida,

National Sagamihara Hospital, Japan

Raphael Micheroli,

University Hospital Zürich, Switzerland

*Correspondence:

Dieter Riethmacher

dieter.riethmacher@nu.edu.kz

Specialty section:

This article was submitted to Inflammation,

a section of the journal

Frontiers in Immunology

Received: 08 June 2021

Accepted: 09 August 2021

Published: 27 August 2021

Citation

Sonnenberg-Riethmacher E, Miehe M and Riethmacher D (2021) Periostin in

Allergy and Inflammation.

Front. Immunol. 12:722170.

doi: 10.3389/fimmu.2021.722170
Matricellular proteins are involved in the crosstalk between cells and their environment and thus play an important role in allergic and inflammatory reactions. Periostin, a matricellular protein, has several documented and multi-faceted roles in health and disease. It is differentially expressed, usually upregulated, in allergic conditions, a variety of inflammatory diseases as well as in cancer and contributes to the development and progression of these diseases. Periostin has also been shown to influence tissue remodelling, fibrosis, regeneration and repair. In allergic reactions periostin is involved in type 2 immunity and can be induced by IL-4 and IL-13 in bronchial cells. A variety of different allergic diseases, among them bronchial asthma and atopic dermatitis (AD), have been shown to be connected to periostin expression. Periostin is commonly expressed in fibroblasts and acts on epithelial cells as well as fibroblasts involving integrin and NF- $\mathrm{KB}$ signalling. Also direct signalling between periostin and immune cells has been reported. The deposition of periostin in inflamed, often fibrotic, tissues is further fuelling the inflammatory process. There is increasing evidence that periostin is also expressed by epithelial cells in several of the above-mentioned conditions as well as in cancer. Augmented periostin expression has also been associated with chronic inflammation such as in inflammatory bowel disease (IBD). Periostin can be expressed in a variety of different isoforms, whose functions have not been elucidated yet. This review will discuss potential functions of periostin and its different isoforms in allergy and inflammation.

Keywords: periostin, isoforms, allergy, chronic inflammation, IBD, diagnostic marker

\section{INTRODUCTION}

Periostin is a matricellular protein originally isolated from osteoblasts and found to be preferentially expressed in the periosteum $(1,2)$. Periostin contains an $\mathrm{N}$-terminal secretory signal peptide, followed by a cysteine-rich domain (EMI domain), four internal homologous repeats (FAS domains), and a Cterminal hydrophilic domain that is alternatively spliced (1-3) (Figure 1). The four internal repeats exhibit homology to the axon guidance protein fasciclin I that is involved in the development of the nervous system in invertebrates and therefore were named fasciclin domains. The EMI domain,

Abbreviations: AC, Allergic conjunctivitis; AD, Atopic dermatitis; AS, Ankylosing Spondylitis; CD, Crohn's disease; CRS, Chronic Rhinosinusitis; CSU, Chronic spontaneous urticarial; ECM, extracellular matrix; EGID, Eosinophilic gastrointestinal disorder; EMI-domain, cysteine-rich domain; EMT, epithelial-mesenchymal transition; EoE, eosinophilic esophagitis; HSPGs, heparan sulfate proteoglycans; IBD, inflammatory bowel disease; IF, idiopathic pulmonary fibrosis; IL, interleukin; MMP, matrix metalloproteinases; UC, ulcerative colitis. 


\section{N EMI-domain \\ FAS-domain \\ C-terminal splicing
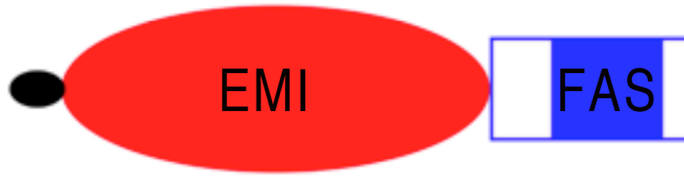 \\ FAS

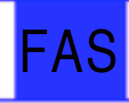 \\ FAS
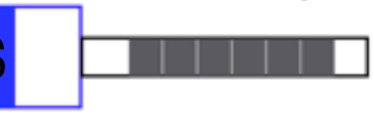 \\ collagen / fibronectin \\ integrins / tenascinC / BMP \\ heparin / HSPGs}

FIGURE 1 | Periostin schematic structure: Periostin is a secretory protein with a multi-domain structure, consisting of a secretion signal peptide, a N-terminal cysteine-rich EMI domain, four internal FAS domains and a C-terminal hydrophilic domain that can be alternatively spliced. The EMI domain interacts with collagen and fibronectin, while the FAS domains can bind to integrins, tenascin-C and BMP. The C-terminal domain shows a high degree of alternative splicing, see also

Figure $\mathbf{3}$ and can bind to heparin and HSPGs.

named after a domain first described in the EMILIN family, can bind to collagen I and fibronectin, while the FAS-domains bind to tenascin- $\mathrm{C}$ and bone morphogenic protein 1 (BMP1) (4-6) (Figure 1). The C-terminal domain shows a high degree of alternative splicing, is known to bind heparin and heparan sulfate proteoglycans (HSPGs) and to modulate the binding mediated by the other domains (7). As a matricellular protein, periostin is mainly localised in the extracellular matrix (ECM) and some of its activities are mediated by its binding to cell surface receptors of the integrin family (8). Periostin has been shown to be differentially expressed (usually upregulated) in a variety of allergic manifestations, inflammation and tumours. Its expression in a tissue-specific context is regulated by several proteins, including TGF- $\beta 1$ (1), bone morphogenetic proteins (BMP) 2 and 4 (9), various interleukins (IL-3, 4, 6 and 13) (10), erbB3 activation involving neuregulins (NRGs) (11), vascular endothelial growth factor, vitamin $\mathrm{K}$ and others (12). Periostin can influence other signalling pathways including the NF- $\kappa \mathrm{B}$, focal adhesion kinase (FAK), phosphatidylinositol 3-kinase (PI3K)/AKT and Yap/TAZ pathways through its interaction with $\alpha_{\mathrm{v}}$-integrins, transmembrane receptors facilitating adhesion of cells to the ECM. It also regulates the expression of several other genes within its functionally connected network, including collagen, $\alpha$ smooth muscle actin ( $\alpha$-SMA), TGF- $\beta 1$ and various chemokines (Ccl2, Ccl4, Ccl5, Ccl7, Cxcl1, Cxcl2) (12-15). Different splice variants generate different isoforms of periostin (3), and it is conceivable to assume that the different isoforms could be contributing to the huge variety of functions reported for periostin. Among these multiple functions, listed in Figure 2 and Table 1, there are epithelial-mesenchymal transition, niche

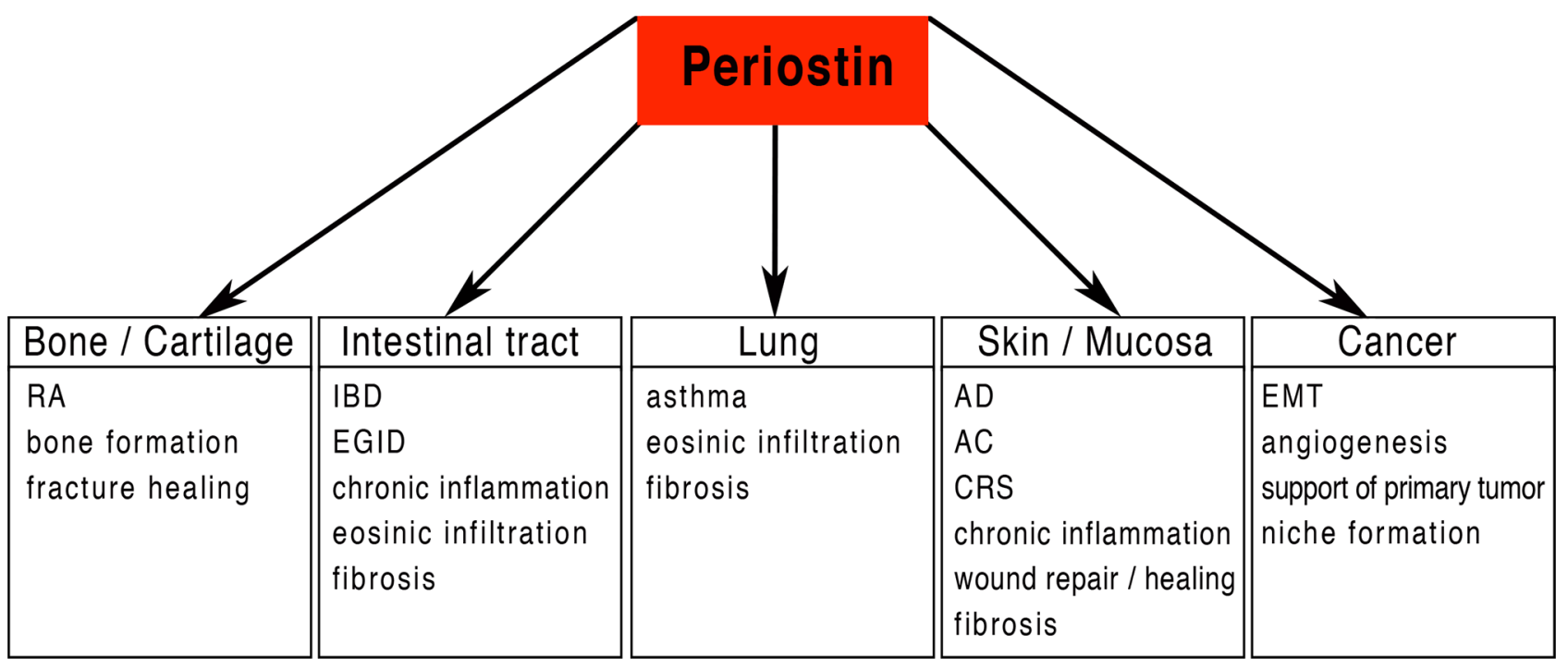

FIGURE 2 | Periostin potential functional implications: Periostin is implicated in a large number of physiological and pathological processes including the attraction and infiltration of inflammatory cells in a variety of different organs/tissues. Periostin is in a key position for driving chronic inflammation and fibrosis in various tissues. RA, Rheumatoid arthritis; IBD, Inflammatory bowel disease; EGID, Eosinophilic gastrointestinal disorder; AD, Atopic dermatitis; AC, Allergic conjunctivitis; CRS, Chronic Rhinosinusitis; EMT, epithelial-mesenchymal transition. 
TABLE 1 | Periostin as a diagnostic marker and/or potential therapeutic target in different organs, illnesses and processes.

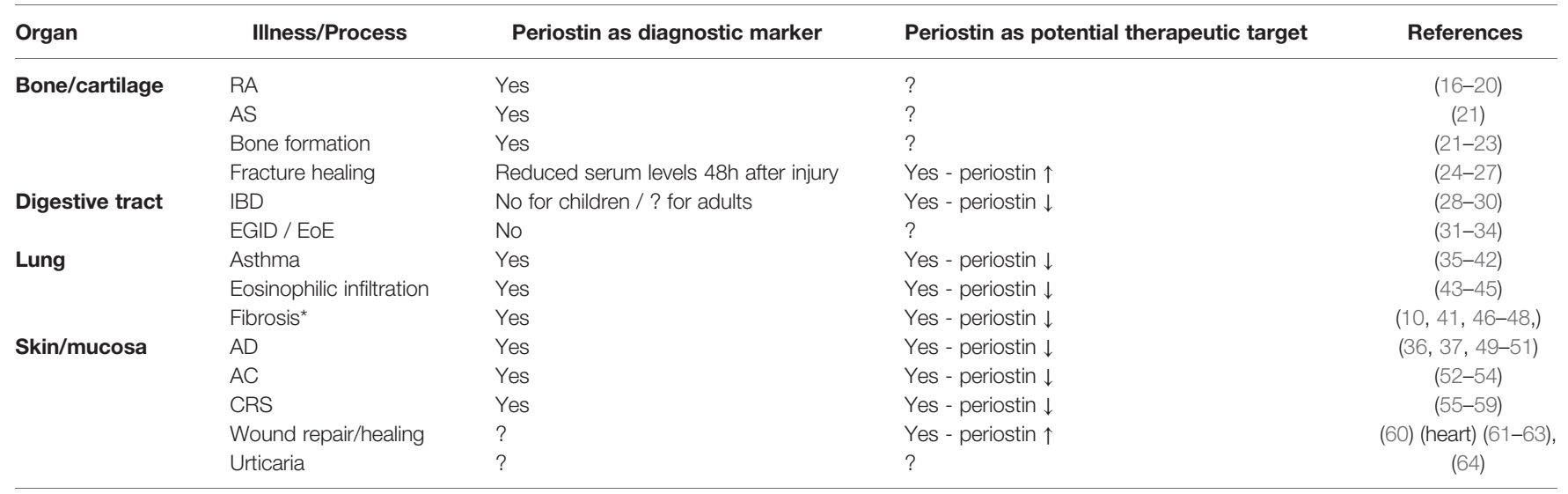

In this table we listed several organs, illnesses and processes in which evidence suggests periostin fulfils important functions and could be valuable diagnostic marker or therapeutic target. For diagnostic marker a yes means that there is published literature that serum levels of periostin are altered in correlation to the disease status and or healthy controls in humans. For therapeutic target the question mark (?) expresses that currently there is no strong evidence that periostin is a potential candidate, while yes means that either increasing ( $\uparrow$ ) or decreasing ( $\downarrow)$ periostin has shown beneficial effects in cell culture and/or animal experiments. The asterisk (*) next to fibrosis reflects that it is listed under lung but as a process applies to other organs as well (e.g. skin, heart, intestine). When searching https://clinicaltrials.gov/ with periostin there are $>50$ trials indicated with at least 10 listing periostin in the title or as intervention, demonstrating that there is increasing interest in periostin as a diagnostic marker or therapeutic agent. RA, Rheumatoid arthritis; AS, Ankylosing Spondylitis; IBD, Inflammatory bowel disease; EGID, Eosinophilic gastrointestinal disorder; EoE, eosinophilic esophagitis; AD, Atopic dermatitis; AC, Allergic conjunctivitis; CRS, Chronic Rhinosinusitis.Additional supporting references $(24-27,34,42,51,62,63)$.

formation, regeneration, tissue repair, inflammatory processes, fibrosis and angiogenesis (10, 35, 65-68). Regeneration and repair is delayed in the absence of periostin $(60,61,69)$, however, its expression is not always beneficial as periostin can also be a driver of fibrosis $(46,70,71)$. EMT has been shown to be involved in fibrosis (72) and periostin is an important player in EMT (73-75). Cell proliferation has been shown to be enhanced by periostin during normal development and in disease (70, 7678). Angiogenesis, which is a prerequisite for a variety of processes in development and disease, is also positively influenced by the expression of periostin $(66,79)$. Another function of periostin is the facilitation of migration $(11,77,80,81)$. Several pathways activated by periostin during these processes have been elucidated $(2,4,11,35,66,73,79,80,82)$. However, little information is available on the different isoforms and how they might contribute to these processes.

The involvement of periostin has been well described across a spectrum of allergic, inflammatory and fibrotic conditions including inflammatory conditions of the respiratory tract (asthma, chronic obstructive pulmonary disease, allergic rhinitis, idiopathic pulmonary fibrosis), systemic sclerosis and scleroderma, atherosclerosis, fibrosis, renal interstitial fibrosis, hepatic fibrosis, inflammatory bowel disease and others (83). In this review, we will discuss the function of periostin in allergy and inflammation, specifically taking into account the isoforms identified so far.

\section{PERIOSTIN IN ALLERGY AND CHRONIC INFLAMMATION}

Periostin has been linked to allergy and inflammation in a variety of different organs (Figure $\mathbf{2}$ and Table 1). It is widely accepted that type 2 (T2) immunity is dominant in allergic inflammation. Type 2 immunity cytokines interleukins IL-4, IL-5 and IL-13 are important in humoral immunity and protection from helminth infection and are central to the pathogenesis of many allergic inflammatory diseases $(84,85)$. IL-4, IL-5 and IL-13 are produced by $\mathrm{T}$ helper 2 (Th2) cells, follicular helper $\mathrm{T}$ cells, eosinophils, mast cells and basophils (86-89).

Binding of IL-4 and IL-13 to their receptors upregulates expression of periostin in a STAT- 6 and SOX11 dependent manner, either directly or indirectly $(36,89-92)$. Furthermore, it was reported that periostin supports $\alpha_{M} \beta_{3}$ integrin-mediated adhesion and migration of IL-5 stimulated eosinophils (43-45).

Periostin has been shown to be upregulated in the subepithelial region in asthma (10), AD (37, 49), allergic conjunctivitis (AC) (52), eosinophilic esophagitis (EoE) (31) and familial idiopathic pulmonary fibrosis (IPF) $(47,48)$. Periostin is also upregulated in chronic inflammations such as IBD and rheumatoid arthritis (RA) $(16,28,29)$. Interestingly, IL24 and STAT-3 as downstream effectors of periostin are enhancing the epithelial-barrier dysfunction thereby further fuelling the inflammatory process (92). All these illnesses entail inflammation followed by regeneration of tissue, in which locally expressed periostin plays an important part.

Macrophages are known to be involved in allergic diseases, however their specific roles are not fully understood. It is known that some macrophage types may exacerbate (M1, M2a and $\mathrm{M} 2 \mathrm{~b}$ ) or reduce (M2c, M2d) allergic reactions (93). In asthma, lung-resident alveolar macrophages serve to maintain homeostasis in this organ by supressing inflammation, while macrophages derived from immigrating cells promote allergic reactions (94-96). Noteworthily, in an investigation on peripheral nerves, periostin was shown to chemotactically attract macrophages to the site of allergic reactions (97). However, Allard et al. did not further characterize which 
macrophage subcategories were attracted via periostin and which types of allergic reactions were enhanced or reduced. In that experimental setting however, absence of periostin leads to a lower macrophage infiltration, thereby lowering inflammation and slowing down disease progression. This suggests that periostin attracts mainly pro-inflammatory macrophages and may apply to other organs and inflammatory situations as well.

\section{ASTHMA}

Periostin is most prominently linked to asthma with reports on its expression and involvement in the development and repair of lung tissue $(38,39,98)$. Periostin is indeed one of the most highly expressed genes in asthma (40).

Bronchial asthma is heterogeneous and can be classified into phenotypes based upon observable clinical or biological characteristics. The different phenotypes are now being defined as asthma endotypes. Various asthma endotypes fall into Th2 ${ }^{\text {hi }}$ and Th $2^{\text {lo }}$ clusters on the basis of the presence or absence of IL-4, IL-5, IL-13 and eosinophils in blood and tissues, respectively (40, 99). Periostin is a distinct signature protein for Th2 ${ }^{\text {hi }}$ asthma (100). Most children and roughly $50 \%$ of adults have allergic asthma of $\mathrm{Th} 2{ }^{\text {hi }}$ endotype. The identification of the specific subtype is fundamental for optimizing the clinical intervention.

The biology of the Th2 response is a critical step towards the understanding of how T2 inflammation leads to disease pathology. The airway epithelial cells of Th2 ${ }^{\text {hi }}$ patients are characterized by increased expression of three genes known to be up-regulated following IL-13 stimulation; periostin is one of these genes (40). IL-13 and IL-4 can both stimulate the secretion of periostin from lung fibroblast (10) and IL-13 can also induce epithelial cell production of periostin. Periostin also induces TGF- $\beta$ signalling, which can further promote ECM deposition and airway remodelling (35). Sub-epithelial periostin promotes adherence and possibly migration of eosinophils into the lung (44).

In asthma, airway remodelling is a common feature that results from the deposition of ECM and the proliferation of smooth muscle cells around large airways essentially narrowing the airway and constricting the airflow (101). Remodelling seems to be associated with severe and steroid-resistant asthma (102, 103), and includes epithelial thickening, myofibroblast differentiation and proliferation, smooth muscle thickening, goblet cell hyperplasia, changes in ECM composition and angiogenesis $(102,104)$. Periostin has been shown to be involved in at least three of these processes: myofibroblast differentiation and proliferation, changes in ECM composition and angiogenesis $(41,66,79)$. In patients with asthma and pulmonary fibrosis, periostin has been localized in the basement membrane of the airway walls $(10,46)$. As mentioned above, IL-4 and IL-13 are responsible for the induction of periostin expression in bronchial asthma, with predominant localization in the thickened basement membrane in lungs of asthmatic patients, where periostin is thought to contribute to the development of sub-epithelial fibrosis (10). In this report, the authors also characterized periostin transcripts and found mainly three variants (see Figure 3). The main variant was the type containing the C-terminal domain exons 19 and 20 and lacking exons 17, 18, and 21 (variant 6, Figure 3). The

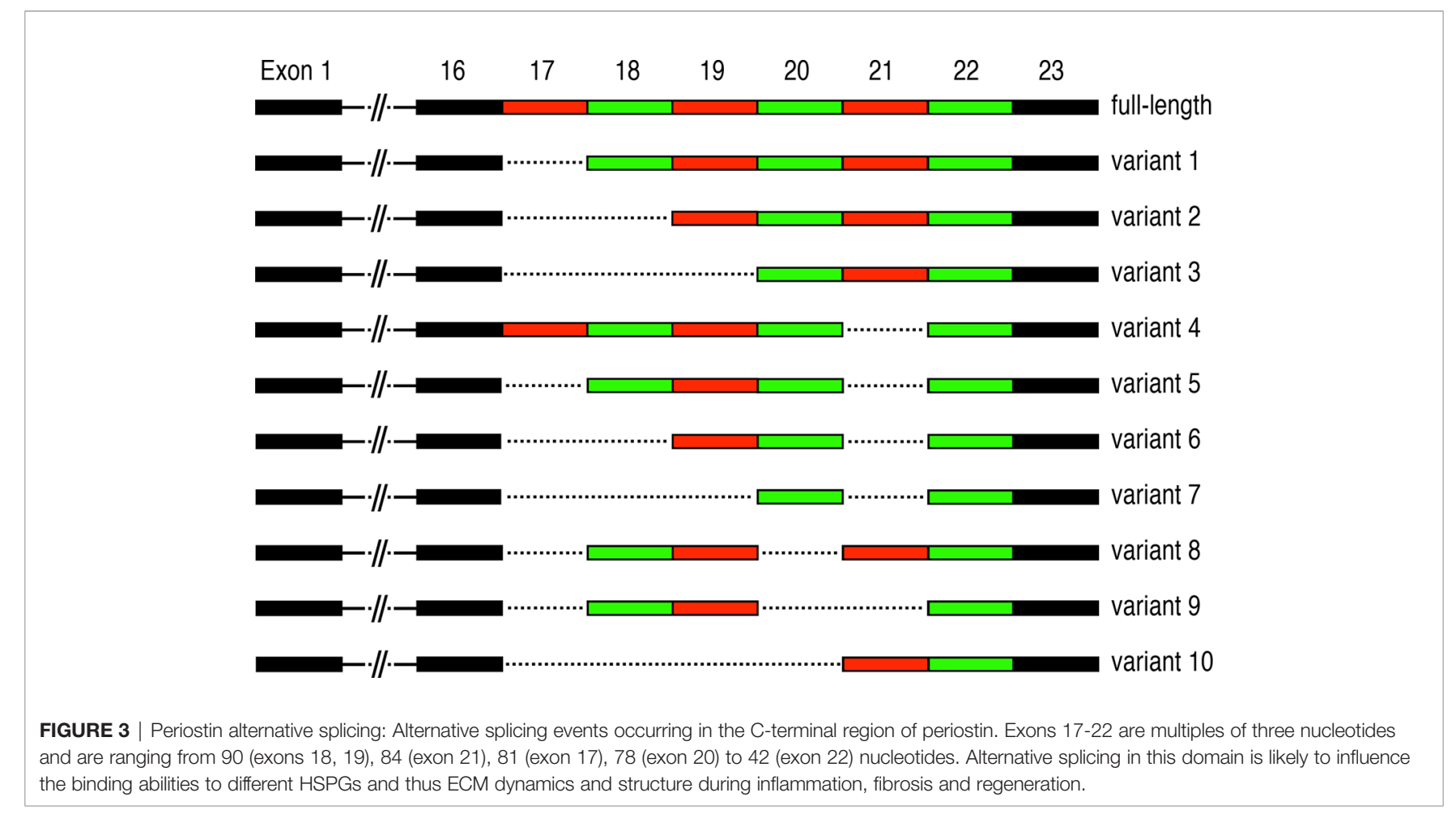


second most abundant transcript additionally lacks exon 19 (variant 7), while the third most frequent transcript only lacks exons 17 and 21 (variant 5) (10). There is no statement regarding the potential functional implications of the expressed variants in this study. Interestingly, there are some controversial results from experiments in mice regarding the role of periostin in asthma. While some studies show that periostin plays a protective role in allergic respiratory diseases (105), one study using periostin homozygous mutant mice seems to implicate a reduction in airway allergic reactions in the absence of periostin (106). These controversial results have not been clarified so far, however they might be due to the use of different allergens, experimental setups and read-outs between the two studies.

\section{CHRONIC RHINOSINUSITIS (CRS)}

CRS is a multifunctional upper respiratory disease that involves chronic inflammation of the nasal cavities and sinuses with a characteristic pattern of cytokine production and remodelling of inflamed tissue (107). CRS is divided into three subgroups based on clinical classification: CRS without nasal polyps, CRS with nasal polyps and allergic fungal rhinosinusitis (107). High levels of periostin expression were first described in sinonasal tissues of CRS patients by Stankovic et al. and later confirmed by other authors (55). In recent studies, periostin seemed to be associated more with eosinophilic CRS with nasal polyps (56), in a generic CRS patient cohort it seemed to be associated with remodelling changes and tissue eosinophilia (57), and it was also described as most likely derived from mast cells (MCs) (58). A review on periostin in CRS cites all relevant articles, however none of these contain any information about the expressed splice variants in CRS (59).

\section{ATOPIC DERMATITIS (AD)}

$\mathrm{AD}$ is a chronic relapsing, highly pruritic inflammatory skin disease $(108,109)$, characterized by epidermal hyperplasia, epithelial barrier dysfunction, infiltration of inflammatory cells (such as lymphocytes, eosinophils, and MCs) as well as fibrosis (110). Excessive Th2 cell responses to environmental stimuli are observed in the skin, particularly in the acute lesions. The pathogenesis of allergic skin inflammation in $\mathrm{AD}$ has been well characterized using various mouse models, for example $\mathrm{Nc} / \mathrm{Nga}$ mice, RelB or Foxp3 deficient mice, thymic stromal lymphopoietin (TSLP) overexpressing mice or epicutaneous sensitization with HDM (for more details see References) (108). Using some of these models it was shown that periostin plays a crucial role in the onset of type 2 inflammation in an $\mathrm{AD}$ mouse model $(37,50)$. While IL- 4 and IL-13 stimulate fibroblasts to produce periostin, periostin in turn directly stimulates the production of TSLP from keratinocytes (50). In AD, activated keratinocytes produce various pro-inflammatory cytokines and chemokines, important for the initiation or amplification of Th2 responses $(111,112)$ and periostin contributes to this via $\alpha_{v}$ integrin signalling, further fuelling the inflammation and disease progression. The IL-13/periostin/IL-24 pathway causes epithelial barrier dysfunction in AD (92). Furthermore, in an AD mouse model, IL-24 produced by keratinocytes is stimulated by IL-13 in a periostin-dependent manner via STAT-6 (92). In the current literature there is no information about periostin splice variants in relation to $\mathrm{AD}$.

Interestingly, even though periostin is a known downstream molecule of IL-4 and IL-13, key cytokines of type 2 immune responses, and up regulation in and contribution to $\mathrm{AD}$ is established (see above) in a study on chronic spontaneous urticaria (CSU) periostin levels were found to be reduced in patients. The authors speculate that this unexpected finding may be due to the antihistamine treatment in CSU patients in their study (64), as histamine is known to directly induce periostin expression (113).

\section{ALLERGIC CONJUNCTIVITIS (AC)}

AC, also called ocular allergy, is a common allergic disorder and present in $30-71 \%$ of patients with allergic rhinitis (114). Upregulation of periostin and eosinophilic infiltration was observed in a mouse model of induced experimental AC, whereas the infiltration of eosinophils was diminished in periostin-deficient mice (53). Furthermore, periostin expression was significantly higher in patients with atopic keratoconjunctivits, vernal keratoconjunctivitis and seasonal AC compared to healthy donors. Periostin levels in tears were positively correlated with complications of atopic keratoconjunctivitis (52). While there is no information on the expressed periostin variants in relation to $\mathrm{AC}$, investigations on the use of periostin as a tear biomarker for this condition are currently ongoing and appear very promising (54).

\section{EOSINOPHIL-ASSOCIATED GASTROINTESTINAL DISORDERS (EGID) INCLUDING EOSINOPHILIC ESOPHAGITIS (EoE)}

EGID are characterized by an inappropriate accumulation of eosinophils within the gastrointestinal tract. It has been highlighted that Th2-driven cytokines play a role in EGID and children and adults with EGID often have positive skin testing for food allergens (115). The most common form of EGID is known as EoE, which is characterized by an infiltration of eosinophils within the esophagus (116). Interestingly, serum levels of periostin were not significantly elevated in patients compared to controls, however there was a correlation between elevated serum levels of IL-13 in conjunction with elevated periostin levels in a sup-population of patients (32). Animal models of EoE have demonstrated that IL-13 can induce EoE through a STAT-6-dependent mechanism (117). IL-13 appears to have an important role in the development of gastrointestinal 
eosinophilia as well as in the development of esophageal remodelling. Recently it was shown that $\alpha_{M} \beta_{2}$ integrins mediate eosinophil tissue residency via periostin in EoE (33). There is no information on expressed splice variants of periostin in either EoE or EGID.

\section{INFLAMMATORY BOWEL DISEASE}

Ulcerative colitis (UC) and Crohn's disease (CD) are examples of IBD in which chronic inflammation of the digestive tract leads to persistent diarrhoea and increases the risk of tumour development in the intestine. UC and CD differ by the location and extent of inflammation, and periostin has been reported to be upregulated in UC and CD patients (29). In an induced IBD model, periostin deficient mice show a lower degree of inflammation compared to wild type mice (29). The precise functions of periostin in the development of IBD have so far not been elucidated. In a recent study, all expressed periostin isoforms in the small intestine were described. Interestingly, periostin variants $1,5,6$ and 7 were detected but not the full length (see details in Figure 3) (28). Periostin has also been linked to the increased risk of colitis-associated colorectal cancer in a mouse model and its expression is also elevated in IBD patients (30). Epidemiologic studies highlight the increased risk of colorectal cancer (CRC) in IBD and generally link this risk to the pro-neoplastic effects of chronic intestinal inflammation (118). Given the altered expression of periostin in acute IBD and during remission in human patients (28), and the link to cancer progression in general as well as in CRC in mouse models, it is tempting to speculate that periostin may likely play a similar role in CRC in human patients $(68,74,81)$.

One IBD complication is the development of conjunctivitis and other ocular problems in 4 to $10 \%$ of the patients, occurring more often in CD than UC (119). In view of the involvement of periostin in $\mathrm{AC}$ and in IBD, it would be interesting to investigate periostin expression levels in intestinal tissues and tears of IBD patients with and without ocular problems.

\section{RHEUMATOID ARTHRITIS (RA) AND ANKYLOSING SPONDYLITIS (AS)}

RA is a chronic inflammatory disease affecting the joints caused by autoantibodies. Periostin has been shown to be upregulated in cells of the synovium and the synovial fluid in RA $(17,18)$. In cultured human chondrocytes, periostin induces the expression of IL-6, IL-8, MMP-1, MMP-3 and MMP13, which could be linked to the development of the disease (19). However, results presented at the ACR/ARHO meeting in 2017 by YunHong Cheon, suggest that periostin has a protective function in RA. In three mouse models of artificially induced arthritis, periostin-deficient mice show a higher level of inflammation (20). These findings are in contradiction to the role periostin plays in other inflammatory diseases and further investigations are required to elucidate the role of periostin in RA. The studies relating to RA lack information about the presence of periostin splice variants.

AS is a form of arthritis that primarily affects the spine and sacroiliac (SI) joints, although other joints can become involved as well (120). Interestingly, an independent negative association between periostin and sclerostin level in AS patients was found, in line with murine studies of mechanical loading in which periostin up-regulates osteoblast activity through inhibition of sclerostin expression (21-23). Since periostin is produced by osteoblasts and is related to the production of new bone, it could be central to the process of excessive bone formation in active AS by inhibiting sclerostin. There is also a clear positive association of periostin with inflammatory markers and disease activity, i.e., higher periostin level with higher disease activity and higher systemic inflammation, but lower level with more extensive radiographic damage (21). Once again, all studies relating to these tissues lack a detailed analysis of periostin splice variants.

\section{PERIOSTIN SERUM LEVEL AS A DIAGNOSTIC MARKER}

Many inflammatory diseases have a complex phenotype and are very heterogeneous, it is therefore important to find biomarkers for a precise medical approach to these diseases. Periostin expression has been linked to Th2 immunity and immune disorders. Because vascular structures run through the mesenchyme, proteins secreted basolaterally are excellent candidates for blood-based biomarkers of epithelial type- 2 activation. Periostin is characterized as secreted from inflamed sites into various body fluids such as blood $(121,122)$, urine (123, 124) and tears (52), and a rise in periostin serum concentration reflects the increase in the inflamed sites (98).

Compared to urine and tears that are locally produced, serum has to be seen in a broader picture. Given that periostin is expressed by a large variety of cells and tissues at any given time one will be able to find it in the serum, generating a certain background level. In addition, periostin levels are age dependent and vary significantly during childhood and adolescence, to reach stable lower levels in the adulthood, thus influencing its usefulness as a marker during these developmental stages (125). In a recent study, an inverse association between circulating periostin and disease activity index in pediatric Crohn's disease has been found, suggesting a more prominent role in repair rather than fuelling inflammatory cascades in this disease. The precise mechanism behind the significantly increased plasma levels of the protein during remission compared to active disease remains unclear (28). Periostin levels have been shown to be elevated in serum of asthmatic patients. However, not all asthmatic patients show this trend. It is widely accepted that asthma is not one single disease, rather a syndrome with different causes and features. The presence of periostin in serum is elevated in late-onset asthmatic patients compared to controls (121, 126), while no significant difference was observed in children. A possible explanation might be given by the already elevated level of periostin in the serum of children and teenagers 
compared to adults, most likely due to enhanced bone metabolism.

Elevated periostin serum levels reflect the $\mathrm{Th} 2^{\text {hi }}$ eosinophilic inflammation in bronchial asthma. The identification of the specific asthma subtype is fundamental for optimizing the clinical intervention. Serum periostin is a distinct signature protein induced by IL-13 and has been utilized as a biomarker for the presence of a Th2 ${ }^{\text {hi }}$ phenotype, which might predict responsiveness to IL-13 antagonism. In asthma, the efficacy of IL-13 antagonists was largely confined to the cohort presenting the IL-13 ${ }^{\text {hi }}$ biomarker periostin (127). The serum level of periostin is a good indicator for the efficiency of the anti-IL-13 antibody lebrikizumab in the treatment of steroid-resistant asthma but may not be the ideal predictor for the $\mathrm{Th} 2^{\text {hi }}$ phenotype (128).

Serum periostin is also increased in CRS, AD and AC (52, $129,130)$. RA also showed elevated periostin levels but it has to be noted that the patients in this study were in remission, not acute cases (16).

Increased periostin levels have also been found in IPF and shown to be a good indicator for progression of the disease (41, 131). However, in a case of acute exacerbation of familial IPF there was no increase of periostin serum level, while high expression of periostin was detected in the fibrotic lesions in the lung (47). There are other allergic conditions, such as allergic rhinitis, in which no elevation of periostin level in the serum could be found (132).

These data show that periostin seems to have different functions in different allergic diseases and more refined experiments have to be conducted in order to fully understand these functions. A limitation in all these studies resides in the determination of the general serum levels of periostin. One way forward could consist in the analysis of the different isoforms, whether there are predominant isoforms in different allergic diseases and whether these isoforms can be found in the serum. It might well be that certain isoforms could be significantly elevated in the serum, while the overall periostin levels appear stable.

\section{OUTLOOK}

Matricellular proteins play an essential role in the regulation of the ECM and several cellular processes via matrix-cellinteraction. Genes encoding matricellular proteins, including periostin, have been shown to have on average four splice variations that can be translated into functional proteins, double the number compared to other genes in the genome (133). Noteworthily, there is growing evidence that splice variants of matricellular proteins play an important role in a variety of diseases (134-137).

Periostin exons 17 to 22 are made up of multiples of three nucleotides, thereby making it feasible for them to be spliced out without changing the reading frame and to be translated into protein. These isoforms only differ at their C-terminus, which has been implied to contain a nuclear localisation signal and to mediate interaction with HSPGs $(3,7)$. It has been shown that stimulation with neuregulin, a ligand for the erbB-receptor-family, can change the localisation of periostin in the cell (11), and that
TGF- $\beta$ can change the isoforms present in a cell (2). Given the strong interaction between TGF- $\beta$ and periostin $(138,139)$, this indicates that different isoforms are located to different areas in the cell or the ECM. Up to now 11 different isoforms have been isolated from different tissues and different stages of development (see Figure 3) (1, 11, 140-143). Different isoforms have been shown to be important in different circumstances, for instance isoforms lacking exon 17 and 21 have been shown to be important in early stages of myocardial infarction (60). Certain isoforms have been linked to renal and non-small cell lung carcinoma $(141,143)$, while two isoforms, which are missing either exon 17 or 21, were found to promote angiogenesis (144). These data show that periostin isoform expression varies significantly between different tissues and different conditions, making the isoforms ideal targets for new, more specific treatment options.

Periostin has been linked to many allergic and inflammatory diseases, showing its importance in these conditions. In some cases, however, periostin is one of the causes or drivers of the disease (i.e., IBD or asthma), while in others periostin expression seems to be influenced by a primary infection exacerbating inflammation. There are also examples such as $\mathrm{RA}$, in which periostin seems to have a protective function against inflammation. Therefore, further investigations are needed to analyse the precise role(s) of periostin in the different allergic and inflammatory diseases. In this respect, a promising direction could be the focus on the different isoforms of periostin. So far, although eleven isoforms have been found, no link to specific allergies or chronic inflammation diseases has been reported. Elucidating a correlation between specific periostin isoforms and inflammatory conditions could prompt towards new treatment options. This is very important, as treatment options are limited for several allergic and inflammatory diseases. In IBD for example, treatment options are aminosalicylate, immunosuppressants, antibiotics and specific antibody treatments. Anti-TNF antibodies are the most prominent treatment of IBD, however, they are only effective in about $50 \%$ of the patients and responsiveness to the treatment fades with time, reflecting the essential need for new specific drugs. Antibodies specific for periostin isoforms or compounds blocking specific interactions could represent possible alternatives in future treatments.

Currently available data reviewed here (see also Table 1) show that periostin levels in the blood are elevated in some diseases (i.e., asthma, CRS, AD and AC), while no change can be seen in other diseases such as familial IPF and allergic rhinitis, or an inverse correlation with disease activity was described as in pediatric Crohn's disease. It would be interesting to analyse the isoform expression in all these conditions, possibly link specific isoforms to specific conditions and test if those isoforms are also elevated in the plasma. This would provide further insight to the function of the different isoforms and possibly help to further establish periostin levels in the blood as diagnostic markers for specific diseases.

\section{AUTHOR CONTRIBUTIONS}

All three authors provided input to the writing of this review by reading and analysing primary publications, on the content of the review as well as writing and editing of the review. DR edited and formatted the final version and created all figures. ES-R and 
DR generated the table. All authors contributed to the article and approved the submitted version.

\section{FUNDING}

This review was written at the Nazarbayev University and the University of Aarhus. The review was supported by Nazarbayev

\section{REFERENCES}

1. Takeshita S, Kikuno R, Tezuka K, Amann E. Osteoblast-Specific Factor 2: Cloning of a Putative Bone Adhesion Protein With Homology With the Insect Protein Fasciclin I. Biochem J (1993) 294(Pt 1):271-8. doi: 10.1042/ bj2940271

2. Horiuchi K, Amizuka N, Takeshita S, Takamatsu H, Katsuura M, Ozawa H, et al. Identification and Characterization of a Novel Protein, Periostin, With Restricted Expression to Periosteum and Periodontal Ligament and Increased Expression by Transforming Growth Factor Beta. J Bone Miner Res (1999) 14(7):1239-49. doi: 10.1359/jbmr.1999.14.7.1239

3. Hoersch S, Andrade-Navarro MA. Periostin Shows Increased Evolutionary Plasticity in its Alternatively Spliced Region. BMC Evol Biol (2010) 10:30. doi: 10.1186/1471-2148-10-30

4. Kii I, Nishiyama T, Li M, Matsumoto K, Saito M, Amizuka N, et al. Incorporation of Tenascin-C Into the Extracellular Matrix by Periostin Underlies an Extracellular Meshwork Architecture. J Biol Chem (2010) 285 (3):2028-39. doi: 10.1074/jbc.M109.051961

5. Maruhashi T, Kii I, Saito M, Kudo A. Interaction Between Periostin and BMP-1 Promotes Proteolytic Activation of Lysyl Oxidase. J Biol Chem (2010) 285(17):13294-303. doi: 10.1074/jbc.M109.088864

6. Norris RA, Damon B, Mironov V, Kasyanov V, Ramamurthi A, MorenoRodriguez R, et al. Periostin Regulates Collagen Fibrillogenesis and the Biomechanical Properties of Connective Tissues. J Cell Biochem (2007) 101 (3):695-711. doi: 10.1002/jcb.21224

7. Kii I, Ito H. Periostin and its Interacting Proteins in the Construction of Extracellular Architectures. Cell Mol Life Sci (2017) 74(23):4269-77. doi: 10.1007/s00018-017-2644-4

8. Kudo A, Kii I. Periostin Function in Communication With Extracellular Matrices. J Cell Communication Signaling (2018) 12(1):301-8. doi: 10.1007/ s12079-017-0422-6

9. Lindner V, Wang Q, Conley BA, Friesel RE, Vary CP. Vascular Injury Induces Expression of Periostin: Implications for Vascular Cell Differentiation and Migration. Arterioscler Thromb Vasc Biol (2005) 25 (1):77-83. doi: 10.1161/01.ATV.0000149141.81230.c6

10. Takayama G, Arima K, Kanaji T, Toda S, Tanaka H, Shoji S, et al. Periostin: A Novel Component of Subepithelial Fibrosis of Bronchial Asthma Downstream of IL-4 and IL-13 Signals. J Allergy Clin Immunol (2006) 118 (1):98-104. doi: 10.1016/j.jaci.2006.02.046

11. Sonnenberg-Riethmacher E, Miehe M, Riethmacher D. Promotion of Periostin Expression Contributes to the Migration of Schwann Cells. J Cell Sci (2015) 128(17):3345-55. doi: 10.1242/jcs.174177

12. Conway SJ, Izuhara K, Kudo Y, Litvin J, Markwald R, Ouyang G, et al. The Role of Periostin in Tissue Remodeling Across Health and Disease. Cell Mol Life Sci (2014) 71(7):1279-88. doi: 10.1007/s00018-013-1494-y

13. Norris RA, Moreno-Rodriguez R, Hoffman S, Markwald RR. The Many Facets of the Matricelluar Protein Periostin During Cardiac Development, Remodeling, and Pathophysiology. J Cell Commun Signal (2009) 3(3-4):27586. doi: 10.1007/s12079-009-0063-5

14. Uchida M, Shiraishi H, Ohta S, Arima K, Taniguchi K, Suzuki S, et al. Periostin, a Matricellular Protein, Plays a Role in the Induction of Chemokines in Pulmonary Fibrosis. Am J Respir Cell Mol Biol (2012) 46 (5):677-86. doi: 10.1165/rcmb.2011-0115OC

15. Xu M, Chen D, Zhou H, Zhang W, Xu J, Chen L. The Role of Periostin in the Occurrence and Progression of Eosinophilic Chronic Sinusitis With Nasal Polyps. Sci Rep (2017) 7(1):9479. doi: 10.1038/s41598-017-08375-2
University Faculty Development Grants (FDCRGP) to DR (090118FD5310), (021220FD2751) and to ESR (110119FD4510).

\section{ACKNOWLEDGMENTS}

The authors thank Dr. Luca Vangelista for carefully revising and commenting the manuscript.

16. Kerschan-Schindl K, Ebenbichler G, Foeger-Samwald U, Leiss H, Gesslbauer C, Herceg M, et al. Rheumatoid Arthritis in Remission: Decreased Myostatin and Increased Serum Levels of Periostin. Wien Klin Wochenschr (2018) 131:1-7. doi: 10.1007/s00508-018-1386-0

17. Brown JM, Mantoku A, Sabokbar A, Oppermann U, Hassan AB, Kudo A, et al. Periostin Expression in Neoplastic and non-Neoplastic Diseases of Bone and Joint. Clin Sarcoma Res (2018) 8:18. doi: 10.1186/s13569-018-0105-y

18. Kasperkovitz PV, Timmer TCG, Smeets TJ, Verbeet NL, Tak PP, van Baarsen LGM, et al. Fibroblast-Like Synoviocytes Derived From Patients With Rheumatoid Arthritis Show the Imprint of Synovial Tissue Heterogeneity: Evidence of a Link Between an Increased MyofibroblastLike Phenotype and High-Inflammation Synovitis. Arthritis Rheum (2005) 52(2):430-41. doi: 10.1002/art.20811

19. Chijimatsu R, Kunugiza Y, Taniyama Y, Nakamura N, Tomita T, Yoshikawa H. Expression and Pathological Effects of Periostin in Human Osteoarthritis Cartilage. BMC Musculoskelet Disord (2015) 16:215. doi: 10.1186/s12891015-0682-3

20. Cheon YH. Periostin Deficiency Exacerbates Joint Inflammation and Bone Destruction in Mouse Models of Rheumatoid Arthritis [abstract]. Arthritis Rheumatol (2017) 69(suppl 10).

21. Sakellariou GT, Anastasilakis AD, Bisbinas I, Oikonomou D, Gerou S, Polyzos SA, et al. Circulating Periostin Levels in Patients With AS: Association With Clinical and Radiographic Variables, Inflammatory Markers and Molecules Involved in Bone Formation. Rheumatol (Oxford England) (2015) 54(5):908-14. doi: 10.1093/rheumatology/keu425

22. Bonnet N, Standley KN, Bianchi EN, Stadelmann V, Foti M, Conway SJ, et al. The Matricellular Protein Periostin is Required for Sost Inhibition and the Anabolic Response to Mechanical Loading and Physical Activity. J Biol Chem (2009) 284(51):35939-50. doi: 10.1186/s13223-018-0254-9

23. Briot K, Paternotte S, Borderie D, Miceli-Richard C, Dougados M, Roux C. Serum Periostin: A New Marker of Local Bone Formation in Early Inflammatory Back Pain: Results From the DESIR Cohort, in: 2013ACR/ ARHP Annual Meeting, American College of Rheumatology: Meeting abstract (session title: Spondylarthropathies and Psoriatic Arthritis: Clinical Aspects and Treatment: II). (2013).

24. Heo SC, Shin WC, Lee MJ, Kim BR, Jang IH, Choi E-J, et al. Periostin Accelerates Bone Healing Mediated by Human Mesenchymal Stem CellEmbedded Hydroxyapatite/Tricalcium Phosphate Scaffold. PloS One (2015) 10(3):e0116698. doi: 10.1371/journal.pone.0116698

25. Duchamp de Lageneste O, Julien A, Abou-Khalil R, Frangi G, Carvalho C, Cagnard N, et al. Periosteum Contains Skeletal Stem Cells With High Bone Regenerative Potential Controlled by Periostin. Nat Commun (2018) 9 (1):773. doi: 10.1038/s41467-018-03124-z

26. Duchamp de Lageneste O, Colnot C. Periostin in Bone Regeneration. In: A Kudo, editor. Periostin. Singapore: Springer Singapore (2019). doi: 10.1007/ 978-981-13-6657-4_6

27. Varughese R, Semprini R, Munro C, Fingleton J, Holweg C, Weatherall M, et al. Serum Periostin Levels Following Small Bone Fractures, Long Bone Fractures and Joint Replacements: An Observational Study. Allergy Asthma Clin Immunol (2018) 14:30. doi: 10.1186/s13223-018-0254-9

28. Coelho T, Sonnenberg-Riethmacher E, Gao Y, Mossotto E, Khojanazarov A, Griffin A, et al. Expression Profile of the Matricellular Protein Periostin in Paediatric Inflammatory Bowel Disease. Sci Rep (2021) 11(1):6194. doi: 10.1038/s41598-021-85096-7

29. Koh SJ, Choi Y, Kim BG, Lee KL, Kim DW, Kim JH, et al. Matricellular Protein Periostin Mediates Intestinal Inflammation Through the Activation 
of Nuclear Factor kappaB Signaling. PloS One (2016) 11(2):e0149652. doi: 10.1371/journal.pone.0149652

30. Koh SJ, Kim JW, Kim BG, Lee KL, Kim DW, Kim JS. Matricellular Protein Periostin Promotes Colitis-Associated Colon Tumorigenesis in Mice. Carcinogenesis (2018) 40(1):102-11. doi: 10.1093/carcin/bgy120

31. Politi E, Angelakopoulou A, Grapsa D, Zande M, Stefanaki K, Panagiotou I, et al. Filaggrin and Periostin Expression Is Altered in Eosinophilic Esophagitis and Normalized With Treatment. J Pediatr Gastroenterol Nutr (2017) 65(1):47-52. doi: 10.1097/MPG.0000000000001419

32. Dellon ES, Higgins LL, Beitia R, Rusin S, Woosley JT, Veerappan R, et al. Prospective Assessment of Serum Periostin as a Biomarker for Diagnosis and Monitoring of Eosinophilic Oesophagitis. Aliment Pharmacol Ther (2016) 44 (2):189-97. doi: 10.1172/JCI58978

33. Vimalathas P, Farris A, Letner D, Deshpande V, Yajnik V, Shreffler W, et al. Integrin alphaM Activation and Upregulation on Esophageal Eosinophils and Periostin-Mediated Eosinophil Survival in Eosinophilic Esophagitis. Immunol Cell Biol (2018) 96(4):426-38. doi: 10.1111/imcb.12018

34. Wechsler JB, Hirano I. Biological Therapies for Eosinophilic Gastrointestinal Diseases. J Allergy Clin Immunol (2018) 142(1):24-+. doi: 10.1016/ j.jaci.2018.05.018

35. Sidhu SS, Yuan S, Innes AL, Kerr S, Woodruff PG, Hou L, et al. Roles of Epithelial Cell-Derived Periostin in TGF-Beta Activation, Collagen Production, and Collagen Gel Elasticity in Asthma. Proc Natl Acad Sci USA (2010) 107(32):14170-5. doi: 10.1073/pnas.1009426107

36. Mitamura Y, Nunomura S, Nanri Y, Arima K, Yoshihara T, Komiya K, et al. Hierarchical Control of Interleukin 13 (IL-13) Signals in Lung Fibroblasts by STAT6 and SOX11. J Biol Chem (2018) 293(38):14646-58. doi: 10.1074/ jbc.RA117.001364

37. Masuoka M, Shiraishi H, Ohta S, Suzuki S, Arima K, Aoki S, et al. Periostin Promotes Chronic Allergic Inflammation in Response to Th2 Cytokines. J Clin Invest (2012) 122(7):2590-600. doi: 10.1172/JCI58978

38. Izuhara $\mathrm{K}$, Matsumoto $\mathrm{H}$, Ohta $\mathrm{S}$, Ono J, Arima $\mathrm{K}$, Ogawa $\mathrm{M}$. Recent Developments Regarding Periostin in Bronchial Asthma. Allergol Int (2015) 64 Suppl:S3-10. doi: 10.1016/j.alit.2015.04.012

39. Izuhara K, Conway SJ, Moore BB, Matsumoto H, Holweg CT, Matthews JG, et al. Roles of Periostin in Respiratory Disorders. Am J Respir Crit Care Med (2016) 193(9):949-56. doi: 10.1164/rccm.201510-2032PP

40. Woodruff PG, Boushey HA, Dolganov GM, Barker CS, Yang YH, Donnelly S, et al. Genome-Wide Profiling Identifies Epithelial Cell Genes Associated With Asthma and With Treatment Response to Corticosteroids. Proc Natl Acad Sci USA (2007) 104(40):15858-63. doi: 10.1073/ pnas.0707413104

41. O'Dwyer DN, Moore BB. The Role of Periostin in Lung Fibrosis and Airway Remodeling. Cell Mol Life Sci (2017) 74(23):4305-14. doi: 10.1007/s00018$017-2649-\mathrm{z}$

42. Takahashi K, Meguro K, Kawashima H, Kashiwakuma D, Kagami SI, Ohta S, et al. Serum Periostin Levels Serve as a Biomarker for Both Eosinophilic Airway Inflammation and Fixed Airflow Limitation in Well-Controlled Asthmatics. J Asthma (2019) 56(3):236-43. doi: 10.1080/02770903.2018.1455855

43. Johansson MW, Khanna M, Bortnov V, Annis DS, Nguyen CL, Mosher DF. IL-5-Stimulated Eosinophils Adherent to Periostin Undergo Stereotypic Morphological Changes and ADAM8-Dependent Migration. Clin Exp Allergy (2017) 47(10):1263-74. doi: 10.1111/cea.12934

44. Johansson MW, Annis DS, Mosher DF. Alpha(M)beta(2) Integrin-Mediated Adhesion and Motility of IL-5-Stimulated Eosinophils on Periostin. Am J Respir Cell Mol Biol (2013) 48(4):503-10. doi: 10.1165/rcmb.2012-0150OC

45. Barretto KT, Swanson CM, Nguyen CL, Annis DS, Esnault SJ, Mosher DF, et al. Control of Cytokine-Driven Eosinophil Migratory Behavior by TGFBeta-Induced Protein (TGFBI) and Periostin. PloS One (2018) 13(7): e0201320. doi: 10.1371/journal.pone.0201320

46. Naik PK, Bozyk PD, Bentley JK, Popova AP, Birch CM, Wilke CA, et al. Periostin Promotes Fibrosis and Predicts Progression in Patients With Idiopathic Pulmonary Fibrosis. Am J Physiol Lung Cell Mol Physiol (2012) 303(12):L1046-56. doi: 10.1152/ajplung.00139.2012

47. Murata K, Koga Y, Kasahara N, Hachisu Y, Nunomura S, Nakajima N, et al. Accumulation of Periostin in Acute Exacerbation of Familial Idiopathic Pulmonary Fibrosis. J Thorac Dis (2018) 10(7):E587-91. doi: 10.21037/ jtd.2018.06.96
48. Yoshihara T, Nanri Y, Nunomura S, Yamaguchi Y, Feghali-Bostwick C, Ajito K, et al. Periostin Plays a Critical Role in the Cell Cycle in Lung Fibroblasts. Respir Res (2020) 21(1):38. doi: 10.1016/j.alit.2018.09.007

49. Herro R, Shui JW, Zahner S, Sidler D, Kawakami Y, Kawakami T, et al. LIGHT-HVEM Signaling in Keratinocytes Controls Development of Dermatitis. J Exp Med (2018) 215(2):415-22. doi: 10.1084/jem.20170536

50. Shiraishi H, Masuoka M, Ohta S, Suzuki S, Arima K, Taniguchi K, et al. Periostin Contributes to the Pathogenesis of Atopic Dermatitis by Inducing TSLP Production From Keratinocytes. Allergol International: Off J Japanese Soc Allergol (2012) 61(4):563-72. doi: 10.1097/MLG.0b013e31816b4b6f

51. Kou K, Okawa T, Yamaguchi $Y$, Ono J, Inoue Y, Kohno M, et al. Periostin Levels Correlate With Disease Severity and Chronicity in Patients With Atopic Dermatitis. Br J Dermatol (2014) 171(2):283-91. doi: 10.1111/bjd.12943

52. Fujishima H, Okada N, Matsumoto K, Fukagawa K, Igarashi A, Matsuda A, et al. The Usefulness of Measuring Tear Periostin for the Diagnosis and Management of Ocular Allergic Diseases. J Allergy Clin Immunol (2016) 138 (2):459-467 e2. doi: 10.1016/j.jaci.2015.11.039

53. Asada $\mathrm{Y}$, Okano M, Ishida W, Iwamoto S, Fukuda K, Hirakata T, et al. Periostin Deletion Suppresses Late-Phase Response in Mouse Experimental Allergic Conjunctivitis. Allergol International: Off J Japanese Soc Allergol (2019) 68(2):233-9. doi: 10.1016/j.alit.2018.09.007

54. Shoji J. Ocular Allergy Test and Biomarkers on the Ocular Surface: Clinical Test for Evaluating the Ocular Surface Condition in Allergic Conjunctival Diseases. Allergol International: Off J Japanese Soc Allergol (2020) 69(4):496504. doi: $10.1177 / 0194599819838782$

55. Stankovic KM, Goldsztein H, Reh DD, Platt MP, Metson R. Gene Expression Profiling of Nasal Polyps Associated With Chronic Sinusitis and AspirinSensitive Asthma. Laryngoscope (2008) 118(5):881-9. doi: 10.1083/ JCB1802OIA7

56. Yang HW, Park JH, Shin JM, Lee HM. Glucocorticoids Ameliorate Periostin-Induced Tissue Remodeling in Chronic Rhinosinusitis With Nasal Polyps. Clin Exp Allergy (2018) 10:10. doi: 10.1111/cea.13267

57. Ebenezer JA, Christensen JM, Oliver BG, Oliver RA, Tjin G, Ho J, et al. Periostin as a Marker of Mucosal Remodelling in Chronic Rhinosinusitis. Rhinology (2017) 55(3):234-41. doi: 10.4193/Rhin 16.215

58. Kim DW, Kulka M, Jo A, Eun KM, Arizmendi N, Tancowny BP, et al. CrossTalk Between Human Mast Cells and Epithelial Cells by IgE-Mediated Periostin Production in Eosinophilic Nasal Polyps. J Allergy Clin Immunol (2017) 139(5):1692-5.e6. doi: 10.1007/s00441-016-2426-6

59. Lehmann AE, Scangas GA, Bergmark RW, El Rassi E, Stankovic KM, Metson R. Periostin and Inflammatory Disease: Implications for Chronic Rhinosinusitis. Otolaryngol Head Neck Surg Off J Am Acad Otolaryngol Head Neck Surg (2019) 160(6):965-73. doi: 10.4168/aair.2016.8.5.457

60. Shimazaki M, Nakamura K, Kii I, Kashima T, Amizuka N, Li M, et al. Periostin is Essential for Cardiac Healing After Acute Myocardial Infarction. J Exp Med (2008) 205(2):295-303. doi: 10.1084/jem.20071297

61. Nishiyama T, Kii I, Kashima TG, Kikuchi Y, Ohazama A, Shimazaki M, et al. Delayed Re-Epithelialization in Periostin-Deficient Mice During Cutaneous Wound Healing. PloS One (2011) 6(4):e18410. doi: 10.1371/journal.pone. 0018410

62. Elliott CG, Forbes TL, Leask A, Hamilton DW. Inflammatory Microenvironment and Tumor Necrosis Factor Alpha as Modulators of Periostin and CCN2 Expression in Human non-Healing Skin Wounds and Dermal Fibroblasts. Matrix Biol (2015) 43:71-84. doi: 10.1016/ j.matbio.2015.03.003

63. Walker JT, McLeod K, Kim S, Conway SJ, Hamilton DW. Periostin as a Multifunctional Modulator of the Wound Healing Response. Cell Tissue Res (2016) 365(3):453-65. doi: 10.1007/s00441-016-2426-6

64. Bae Y, Izuhara K, Ohta S, Ono J, Hong GU, Ro JY, et al. Periostin and Interleukin-13 Are Independently Related to Chronic Spontaneous Urticaria. Allergy Asthma Immunol Res (2016) 8(5):457-60. doi: 10.4168/ aair.2016.8.5.457

65. Hamilton DW. Functional Role of Periostin in Development and Wound Repair: Implications for Connective Tissue Disease. J Cell Commun Signal (2008) 2(1-2):9-17. doi: 10.1007/s12079-008-0023-5

66. Liu Y, Li F, Gao F, Xing L, Qin P, Liang X, et al. Periostin Promotes Tumor Angiogenesis in Pancreatic Cancer via Erk/VEGF Signaling. Oncotarget (2016) 7(26):40148-59. doi: 10.18632/oncotarget.9512 
67. Landry NM, Cohen S, Dixon IMC. Periostin in Cardiovascular Disease and Development: A Tale of Two Distinct Roles. Basic Res Cardiol (2018) 113 (1):1. doi: 10.1007/s00395-017-0659-5

68. Ma H, Wang J, Zhao X, Wu T, Huang Z, Chen D, et al. Periostin Promotes Colorectal Tumorigenesis Through Integrin-FAK-Src Pathway-Mediated YAP/TAZ Activation. Cell Rep (2020) 30(3):793-806.e6. doi: 10.1016/ j.celrep.2019.12.075

69. Shih CH, Lacagnina M, Leuer-Bisciotti K, Proschel C. Astroglial-Derived Periostin Promotes Axonal Regeneration After Spinal Cord Injury. J Neurosci (2014) 34(7):2438-43. doi: 10.1523/JNEUROSCI.2947-13.2014

70. Bible E. Polycystic Kidney Disease: Periostin is Involved in Cell Proliferation and Interstitial Fibrosis in Polycystic Kidney Disease. Nat Rev Nephrol (2014) 10(2):66. doi: 10.1038/nrneph.2013.270

71. Zhao S, Wu H, Xia W, Chen X, Zhu S, Zhang S, et al. Periostin Expression is Upregulated and Associated With Myocardial Fibrosis in Human Failing Hearts. J Cardiol (2014) 63(5):373-8. doi: 10.1016/j.jjcc.2013.09.013

72. Thiery JP, Acloque H, Huang RY, Nieto MA. Epithelial-Mesenchymal Transitions in Development and Disease. Cell (2009) 139(5):871-90. doi: 10.1016/j.cell.2009.11.007

73. Hu WW, Chen PC, Chen JM, Wu YM, Liu PY, Lu CH, et al. Periostin Promotes Epithelial-Mesenchymal Transition via the MAPK/miR-381 Axis in Lung Cancer. Oncotarget (2017) 8(37):62248-60. doi: 10.18632/ oncotarget.19273

74. Lv Y-J, Wang W, Ji C-S, Jia M-R. Xie and B. Hu: Association Between Periostin and Epithelial-Mesenchymal Transition in Esophageal Squamous Cell Carcinoma and its Clinical Significance. Oncol Lett (2017) 14(1):376-82. doi: 10.1016/j.celrep.2018.02.035

75. Piano MA, Brunello A, Cappellesso R, Del Bianco P, Mattiolo A, Fritegotto C, et al. Periostin and Epithelial-Mesenchymal Transition Score as Novel Prognostic Markers for Leiomyosarcoma, Myxofibrosarcoma, and Undifferentiated Pleomorphic Sarcoma. Clin Cancer Research: an Off J Am Assoc Cancer Res (2020) 26(12):2921-31. doi: 10.1177/1010428317694549

76. Ma SM, Chen LX, Lin YF, Yan H, Lv JW, Xiong M, et al. Periostin Promotes Neural Stem Cell Proliferation and Differentiation Following Hypoxic-Ischemic Injury. PloS One (2015) 10(4):e0123585. doi: 10.1371/journal.pone.0123585

77. Wu Z, Dai W, Wang P, Zhang X, Tang Y, Liu L, et al. Periostin Promotes Migration, Proliferation, and Differentiation of Human Periodontal Ligament Mesenchymal Stem Cells. Connect Tissue Res (2018) 59(2):10819. doi: 10.1080/03008207.2017.1306060

78. Gonzalez-Gonzalez L, Alonso J. Periostin: A Matricellular Protein With Multiple Functions in Cancer Development and Progression. Front Oncol (2018) 8:225. doi: 10.3389/fonc.2018.00225

79. Keklikoglou I, Kadioglu E, Bissinger S, Langlois B, Bellotti A, Orend G, et al. Periostin Limits Tumor Response to VEGFA Inhibition. Cell Rep (2018) 22 (10):2530-40. doi: 10.1016/j.celrep.2018.02.035

80. Chuanyu S, Yuqing Z, Chong X, Guowei X, Xiaojun Z. Periostin Promotes Migration and Invasion of Renal Cell Carcinoma Through the Integrin/ Focal Adhesion Kinase/C-Jun N-Terminal Kinase Pathway. Tumour Biol (2017) 39(4):1010428317694549. doi: 10.1177/1010428317694549

81. Malanchi I, Santamaria-Martinez A, Susanto E, Peng H, Lehr HA, Delaloye JF, et al. Interactions Between Cancer Stem Cells and Their Niche Govern Metastatic Colonization. Nature (2011) 481(7379):85-9. doi: 10.1038/nature10694

82. Bentley JK, Chen Q, Hong JY, Popova AP, Lei J, Moore BB, et al. Periostin is Required for Maximal Airways Inflammation and Hyperresponsiveness in Mice. J Allergy Clin Immunol (2014) 134(6):1433-42. doi: 10.1016/ j.jaci.2014.05.029

83. Liu AY, Zheng H, Ouyang G. Periostin, a Multifunctional Matricellular Protein in Inflammatory and Tumor Microenvironments. Matrix Biol (2014) 37:150-6. doi: 10.1016/j.matbio.2014.04.007

84. Paul WE, Zhu J. How are T(H)2-Type Immune Responses Initiated and Amplified? Nat Rev Immunol (2010) 10(4):225-35. doi: 10.1038/nri2735

85. Pulendran B, Artis D. New Paradigms in Type 2 Immunity. Science (2012) 337(6093):431-5. doi: 10.1126/science. 1221064

86. Miyake K, Karasuyama H. Emerging Roles of Basophils in Allergic Inflammation. Allergol Int (2017) 66(3):382-91. doi: 10.1016/ j.alit.2017.04.007

87. Kubo M. T Follicular Helper and TH2 Cells in Allergic Responses. Allergol Int (2017) 66(3):377-81. doi: 10.1016/j.alit.2017.04.006
88. Kabata H, Moro K, Koyasu S, Asano K. Group 2 Innate Lymphoid Cells and Asthma. Allergol Int (2015) 64(3):227-34. doi: 10.1016/j.alit.2015.03.004

89. Izuhara K, Arima K, Kanaji S, Ohta S, Kanaji T. IL-13: A Promising Therapeutic Target for Bronchial Asthma. Curr Med Chem (2006) 13 (19):2291-8. doi: 10.2147/JAA.S104508

90. Goenka S, Kaplan MH. Transcriptional Regulation by STAT6. Immunol Res (2011) 50(1):87-96. doi: 10.1007/s12026-011-8205-2

91. Kelly-Welch AE, Hanson EM, Boothby MR, Keegan AD. Interleukin-4 and Interleukin-13 Signaling Connections Maps. Science (2003) 300(5625):15278. doi: 10.1126/science. 1085458

92. Mitamura Y, Nunomura S, Nanri Y, Ogawa M, Yoshihara T, Masuoka M, et al. The IL-13/Periostin/IL-24 Pathway Causes Epidermal Barrier Dysfunction in Allergic Skin Inflammation. Allergy (2018) 73(9):1881-91. doi: $10.1111 /$ all.13437

93. Jiang Z, Zhu L. Update on the Role of Alternatively Activated Macrophages in Asthma. J Asthma Allergy (2016) 9:101-7. doi: 10.2147/JAA.S104508

94. Lee YG, Jeong JJ, Nyenhuis S, Berdyshev E, Chung S, Ranjan R, et al. Recruited Alveolar Macrophages, in Response to Airway Epithelial-Derived Monocyte Chemoattractant Protein 1/CCl2, Regulate Airway Inflammation and Remodeling in Allergic Asthma. Am J Respir Cell Mol Biol (2015) 52 (6):772-84. doi: 10.1165/rcmb.2014-0255OC

95. Zaslona Z, Przybranowski S, Wilke C, van Rooijen N, Teitz-Tennenbaum S, Osterholzer JJ, et al. Resident Alveolar Macrophages Suppress, Whereas Recruited Monocytes Promote, Allergic Lung Inflammation in Murine Models of Asthma. J Immunol (2014) 193(8):4245-53. doi: 10.4049/ jimmunol.1400580

96. Westphalen K, Gusarova GA, Islam MN, Subramanian M, Cohen TS, Prince AS, et al. Sessile Alveolar Macrophages Communicate With Alveolar Epithelium to Modulate Immunity. Nature (2014) 506(7489):503-6. doi: 10.1038/nature12902

97. Allard DE, Wang Y, Li JJ, Conley B, Xu EW, Sailer D, et al. Schwann CellDerived Periostin Promotes Autoimmune Peripheral Polyneuropathy via Macrophage Recruitment. J Clin Invest (2018) 128(10):4727-41. doi: 10.1172/ JCI99308

98. Izuhara K, Arima K, Ohta S, Suzuki S, Inamitsu M, Yamamoto KI. Periostin in Allergic Inflammation. Allergol Int (2014) 63(2):143-51. doi: 10.2332/ allergolint.13-RAI-0663

99. Woodruff PG, Modrek B, Choy DF, Jia G, Abbas AR, Ellwanger A, et al. THelper Type 2-Driven Inflammation Defines Major Subphenotypes of Asthma. Am J Respir Crit Care Med (2009) 180(5):388-95. doi: 10.1164/ rccm.200903-0392OC

100. Yuyama N, Davies DE, Akaiwa M, Matsui K, Hamasaki Y, Suminami Y, et al. Analysis of Novel Disease-Related Genes in Bronchial Asthma. Cytokine (2002) 19(6):287-96. doi: 10.1016/S1081-1206(10)60087-7

101. Trejo Bittar HE, Yousem SA, Wenzel SE. Pathobiology of Severe Asthma. Annu Rev Pathol (2015) 10:511-45. doi: 10.1146/annurev-pathol-012414-040343

102. Tang ML, Wilson JW, Stewart AG, Royce SG. Airway Remodelling in Asthma: Current Understanding and Implications for Future Therapies. Pharmacol Ther (2006) 112(2):474-88. doi: 10.1016/j.pharmthera.2006.05.001

103. Bumbacea D, Campbell D, Nguyen L, Carr D, Barnes PJ, Robinson D, et al. Parameters Associated With Persistent Airflow Obstruction in Chronic Severe Asthma. Eur Respir J (2004) 24(1):122-8. doi: 10.1016/j.jaci.2015.10.011

104. Royce SG, Tan L, Koek AA, Tang ML. Effect of Extracellular Matrix Composition on Airway Epithelial Cell and Fibroblast Structure: Implications for Airway Remodeling in Asthma. Ann Allergy Asthma Immunol (2009) 102(3):238-46. doi: 10.1016/S1081-1206(10)60087-7

105. Gordon ED, Sidhu SS, Wang ZE, Woodruff PG, Yuan S, Solon MC, et al. A Protective Role for Periostin and TGF-Beta in IgE-Mediated Allergy and Airway Hyperresponsiveness. Clin Exp Allergy (2012) 42(1):144-55. doi: $10.1111 / j .1365-2222.2011 .03840 . x$

106. Sehra S, Yao W, Nguyen ET, Ahyi AN, Tuana FM, Ahlfeld SK, et al. Periostin Regulates Goblet Cell Metaplasia in a Model of Allergic Airway Inflammation. J Immunol (2011) 186(8):4959-66. doi: 10.4049/jimmunol.1002359

107. Hamilos DL. Drivers of Chronic Rhinosinusitis: Inflammation Versus Infection. J Allergy Clin Immunol (2015) 136(6):1454-9. doi: 10.1016/ j.jaci.2015.10.011

108. Oyoshi MK, He R, Kumar L, Yoon J, Geha RS. Cellular and Molecular Mechanisms in Atopic Dermatitis. Adv Immunol (2009) 102:135-226. doi: 10.1016/s0065-2776(09)01203-6 
109. Leung DY, Boguniewicz M, Howell MD, Nomura I, Hamid QA. New Insights Into Atopic Dermatitis. J Clin Invest (2004) 113(5):651-7. doi: $10.1172 /$ jci2 1060

110. Weidinger S, Novak N. Atopic Dermatitis. Lancet (2016) 387(10023):110922. doi: 10.1016/s0140-6736(15)00149-x

111. Kaiko GE, Foster PS. New Insights Into the Generation of Th2 Immunity and Potential Therapeutic Targets for the Treatment of Asthma. Curr Opin Allergy Clin Immunol (2011) 11(1):39-45. doi: 10.1097/ACI.0b013e328342322f

112. Carmi-Levy I, Homey B, Soumelis V. A Modular View of Cytokine Networks in Atopic Dermatitis. Clin Rev Allergy Immunol (2011) 41(3):245-53. doi: 10.1007/s12016-010-8239-6

113. Yang L, Murota H, Serada S, Fujimoto M, Kudo A, Naka T, et al. Histamine Contributes to Tissue Remodeling via Periostin Expression. J Invest Dermatol (2014) 134(8):2105-13. doi: 10.1038/jid.2014.120

114. Leonardi A, Castegnaro A, Valerio ALG, Lazzarini D. Epidemiology of Allergic Conjunctivitis: Clinical Appearance and Treatment Patterns in a PopulationBased Study. Curr Opin Allergy Clin Immunol (2015) 15(5):482-8. doi: 10.1097/ ACI.0000000000000204

115. DeBrosse CW, Rothenberg ME. Allergy and Eosinophil-Associated Gastrointestinal Disorders (EGID). Curr Opin Immunol (2008) 20(6):7038. doi: 10.1016/j.coi.2008.07.010

116. Noguchi T, Nakagome K, Kobayashi T, Uchida Y, Soma T, Nakamoto H, et al. Periostin Upregulates the Effector Functions of Eosinophils. J Allergy Clin Immunol (2016) 138(5):1449-1452.e5. doi: 10.1016/j.jaci.2016.05.020

117. Mishra A, Rothenberg ME. Intratracheal IL-13 Induces Eosinophilic Esophagitis by an IL-5, Eotaxin-1, and STAT6-Dependent Mechanism. Gastroenterology (2003) 125(5):1419-27. doi: 10.1002/art.20811

118. Stidham RW, Higgins PDR. Colorectal Cancer in Inflammatory Bowel Disease. Clinics Colon Rectal Surg (2018) 31(3):168-78. doi: 10.1055/s0037-1602237

119. Mintz R, Feller ER, Bahr RL, Shah SA. Ocular Manifestations of Inflammatory Bowel Disease. Inflamm Bowel Dis (2004) 10(2):135-9. doi: 10.1097/00054725-200403000-00012

120. Zhu W, He X, Cheng K, Zhang L, Chen D, Wang X, et al. Ankylosing Spondylitis: Etiology, Pathogenesis, and Treatments. Bone Res (2019) 7:22. doi: 10.1038/s41413-019-0057-8

121. Matsusaka M, Kabata H, Fukunaga K, Suzuki Y, Masaki K, Mochimaru T, et al. Phenotype of Asthma Related With High Serum Periostin Levels. Allergol Int (2015) 64(2):175-80. doi: 10.1016/j.alit.2014.07.003

122. Kim MA, Izuhara K, Ohta S, Ono J, Yoon MK, Ban GY, et al. Association of Serum Periostin With Aspirin-Exacerbated Respiratory Disease. Ann Allergy Asthma Immunol (2014) 113(3):314-20. doi: 10.1016/j.anai.2014.06.014

123. Hwang JH, Lee JP, Kim CT, Yang SH, Kim JH, An JN, et al. Urinary Periostin Excretion Predicts Renal Outcome in IgA Nephropathy. Am J Nephrol (2016) 44(6):481-92. doi: 10.1159/000452228

124. Satirapoj B, Tassanasorn S, Charoenpitakchai M, Supasyndh O. Periostin as a Tissue and Urinary Biomarker of Renal Injury in Type 2 Diabetes Mellitus. PloS One (2015) 10(4):e0124055. doi: 10.1371/journal.pone.0124055

125. Fujitani H, Kasuga S, Ishihara T, Higa Y, Fujikawa S, Ohta N, et al. AgeRelated Changes in Serum Periostin Level in Allergic and Non-Allergic Children. Allergol International: Off J Japanese Soc Allergol (2019) 68(2):2856. doi: 10.1016/j.alit.2018.12.006

126. Kanemitsu Y, Matsumoto H, Izuhara K, Tohda Y, Kita H, Horiguchi T, et al. Increased Periostin Associates With Greater Airflow Limitation in Patients Receiving Inhaled Corticosteroids. J Allergy Clin Immunol (2013) 132 (2):305-12 e3. doi: 10.1016/j.jaci.2013.04.050

127. Corren J, Lemanske RF, Hanania NA, Korenblat PE, Parsey MV, Arron JR, et al. Lebrikizumab Treatment in Adults With Asthma. N Engl J Med (2011) 365(12):1088-98. doi: 10.1056/NEJMoa1106469

128. Pavlidis S, Takahashi K, Ng Kee Kwong F, Xie J, Hoda U, Sun K, et al. Fan Chung: "T2-High" in Severe Asthma Related to Blood Eosinophil, Exhaled Nitric Oxide and Serum Periostin. Eur Respir J (2019) 53(1):1800938. doi: $10.1183 / 13993003.00938-2018$

129. Ninomiya T, Noguchi E, Haruna T, Hasegawa M, Yoshida T, Yamashita Y, et al. Periostin as a Novel Biomarker for Postoperative Recurrence of Chronic Rhinosinitis With Nasal Polyps. Sci Rep (2018) 8(1):11450. doi: 10.1038/ s41598-018-29612-2
130. Maxfield AZ, Landegger LD, Brook CD, Lehmann AE, Campbell AP, Bergmark RW, et al. Periostin as a Biomarker for Nasal Polyps in Chronic Rhinosinusitis. Otolaryngol Head Neck Surg (2018) 158(1):181-6. doi: $10.1177 / 0194599817737967$

131. Ohta S, Okamoto M, Fujimoto K, Sakamoto N, Takahashi K, Yamamoto H, et al. The Usefulness of Monomeric Periostin as a Biomarker for Idiopathic Pulmonary Fibrosis. PloS One (2017) 12(3):e0174547. doi: 10.1371/ journal.pone.0174547

132. Kim DY, Kim JH, Lee KH, Hong SC, Lee HS, Kang JW. Serum Periostin Level is Not Associated With Allergic Rhinitis or Allergic Sensitization in Korean Children. Int J Pediatr Otorhinolaryngol (2017) 93:24-9. doi: 10.1016/j.ijporl.2016.12.013

133. Viloria K, Hill NJ. Embracing the Complexity of Matricellular Proteins: The Functional and Clinical Significance of Splice Variation. Biomol Concepts (2016) 7(2):117-32. doi: 10.1515/bmc-2016-0004

134. He B, Mirza M, Weber GF. An Osteopontin Splice Variant Induces Anchorage Independence in Human Breast Cancer Cells. Oncogene (2006) 25(15):2192-202. doi: 10.1038/sj.onc.1209248

135. Adams M, Jones JL, Walker RA, Pringle JH, Bell SC. Changes in Tenascin-C Isoform Expression in Invasive and Preinvasive Breast Disease. Cancer Res (2002) 62(11):3289-97.

136. Zduniak K, Ziolkowski P, Ahlin C, Agrawal A, Agrawal S, Blomqvist C, et al. Nuclear Osteopontin-C is a Prognostic Breast Cancer Marker. Br J Cancer (2015) 112(4):729-38. doi: 10.1038/bjc.2014.664

137. Hartung F, Weber GF. RNA Blood Levels of Osteopontin Splice Variants are Cancer Markers. Springerplus (2013) 2(1):110. doi: 10.1186/2193-1801-2-110

138. Hu Q, Tong S, Zhao X, Ding W, Gou Y, Xu K, et al. Periostin Mediates TGFBeta-Induced Epithelial Mesenchymal Transition in Prostate Cancer Cells. Cell Physiol Biochem (2015) 36(2):799-809. doi: 10.1159/000430139

139. Ouanouki A, Lamy S, Annabi B. Periostin, a Signal Transduction Intermediate in TGF-Beta-Induced EMT in U-87MG Human Glioblastoma Cells, and its Inhibition by Anthocyanidins. Oncotarget (2018) 9(31):22023-37. doi: 10.18632/oncotarget.25153

140. Litvin J, Selim AH, Montgomery MO, Lehmann K, Rico MC, Devlin H, et al. Expression and Function of Periostin-Isoforms in Bone. J Cell Biochem (2004) 92(5):1044-61. doi: 10.1002/jcb.20115

141. Morra L, Rechsteiner M, Casagrande S, von Teichman A, Schraml P, Moch H, et al. Characterization of Periostin Isoform Pattern in Non-Small Cell Lung Cancer. Lung Cancer (2012) 76(2):183-90. doi: 10.1016/j.lungcan.2011.10.013

142. Bai Y, Nakamura M, Zhou G, Li Y, Liu Z, Ozaki T, et al. Novel Isoforms of Periostin Expressed in the Human Thyroid. Jpn Clin Med (2010) 1:13-20. doi: $10.4137 / J C M . S 5899$

143. Kim CJ, Isono T, Tambe Y, Chano T, Okabe H, Okada Y, et al. Role of Alternative Splicing of Periostin in Human Bladder Carcinogenesis. Int $J$ Oncol (2008) 32(1):161-9. doi: 10.3892/ijo.32.1.161

144. Nakama T, Yoshida S, Ishikawa K, Kobayashi Y, Abe T, Kiyonari H, et al. Different Roles Played by Periostin Splice Variants in Retinal Neovascularization. Exp Eye Res (2016) 153:133-40. doi: 10.1016/ j.exer.2016.10.012

Conflict of Interest: The authors declare that the research was conducted in the absence of any commercial or financial relationships that could be construed as a potential conflict of interest.

Publisher's Note: All claims expressed in this article are solely those of the authors and do not necessarily represent those of their affiliated organizations, or those of the publisher, the editors and the reviewers. Any product that may be evaluated in this article, or claim that may be made by its manufacturer, is not guaranteed or endorsed by the publisher.

Copyright (c) 2021 Sonnenberg-Riethmacher, Miehe and Riethmacher. This is an open-access article distributed under the terms of the Creative Commons Attribution License (CC BY). The use, distribution or reproduction in other forums is permitted, provided the original author(s) and the copyright owner(s) are credited and that the original publication in this journal is cited, in accordance with accepted academic practice. No use, distribution or reproduction is permitted which does not comply with these terms. 